\title{
Exploring Student and Advisor Experiences in a College-University Pathway Program: A Study of the Bachelor of Commerce Pathway
}

Jennifer Percival, Maurice DiGiuseppe, Bill Goodman, Ann LeSage, Ron Hinch, John Samis, Otto Sanchez, Anna Rodrigues, \& Phil Raby

University of Ontario Institute of Technology

Fabiola Longo

Durham College

Arlene De La Rocha

University of Ontario Institute of Technology/Durham College

\begin{abstract}
Currently, there is great interest across Ontario in the expansion of pathway programs between colleges and universities. Through strategic partnerships, two Ontario-based postsecondary institutions (a college and a university) have developed innovative and effective pathway programs that facilitate the transition of students between institutions for the completion of degrees, diplomas, and certificates. These programs support the training of highly qualified, market-ready graduates. This paper reports on a mixed-methods study of the successes and challenges of a particular Ontario college and university pathway program, with a focus on the Bachelor of Commerce Pathway program. Preliminary results indicate that pathway students were more academically successful than their traditional university student counterparts but did experience a number of challenges in transitioning from college into university. Principal challenges included inefficient communication between program administrators, academic advisors, and students; lack of orientation
\end{abstract}


activities for pathway students; lack of college student preparedness in communication and critical thinking skills; and difficulties experienced by college students integrating into the social-cultural life of the university.

\section{Résumé}

Il existe présentement un grand intérêt partout en Ontario pour l'expansion de programmes de transfert entre collèges et universités. Grâce à des partenariats stratégiques, deux établissements postsecondaires localisés en Ontario (un collège et une université) ont créé des programmes de transferts innovateurs et efficaces qui facilitent la transition des élèves entre les établissements pour l'obtention de diplômes et de certificats. Ces programmes soutiennent la formation de diplômés hautement qualifiés, prêts pour le marché du travail. Le présent article présente une étude de méthodes mixtes portant sur les succès et les défis d'un programme de transfert particulier entre une université et un collège de l'Ontario, en misant particulièrement sur le programme de transfert du baccalauréat en commerce. Les résultats préliminaires indiquent que les étudiants du programme de transfert obtenaient de meilleurs résultats scolaires que leurs homologues aux études universitaires traditionnelles, mais qu'ils ont dû surmonter quelques défis pendant la transition du collège à l'université. Parmi les principaux défis, on trouve une communication inefficace entre les administrateurs de programmes, les conseillers pédagogiques et les étudiants; un manque d'activités d'orientation pour les étudiants des programmes de transfert; un manque de préparation en matière de communication et de pensée critique chez les collégiens; et des difficultés pour les collégiens à intégrer la vie sociale et culturelle de l'université.

\section{Introduction}

In summer 2005, Durham College and the University of Ontario Institute of Technology (UOIT) initiated multiple pathway programs to help college students complete university degrees and university students complete college diplomas and certificates. The majority of these programs have been designed to support students who have completed a two-year college diploma to transition into a four-year university honours degree. Some of these pathway programs include "bridge courses" that college students must complete to qualify for admission to certain university degree programs. Students must complete these bridge courses after having completed a two-year college diploma or three-year advanced college diploma program. Other pathway programs do not include bridge courses, meaning that qualified college students (i.e., those who have completed an appropriate three-year advanced diploma) may enrol in university courses directly (direct entry).

To date, there has not been a review of the pathway programs at these institutions in terms of successes and challenges experienced by their students. There is also very little program-level evidence of the benefits and challenges experienced by students enrolled in these programs. Consequently, this study explored some of the successes and challenges experienced by participants of these programs to inform future development of pathway program policy and practice. 
As a mixed-methods study, this research project involved the collection, analysis, and interpretation of quantitative and qualitative data, with a focus on pathway student grades, and the experiences of pathway students and their academic advisors. This paper presents preliminary findings specific to the Bachelor of Commerce Pathway Program (BCom Pathway), focusing on its strengths and weaknesses, including a comparison of pathway student grade point average (GPA) scores to those of non-pathway four-year university students (traditional students), and factors that facilitate and hinder pathway program enrolment, transition, and completion. Student mobility through the BCom Pathway is particularly important due to the accreditation requirements placed on graduates by professional accreditation bodies such as the Chartered Professional Accountants of Ontario and the Human Resources Professionals Association. Some recommendations for BCom Pathway improvement and suggestions for further research are provided.

\section{Background}

Historically, Ontario college education engaged students in occupation-specific training with little emphasis on preparing students to transfer to university (Skolnik, 1995). However, today's students are more likely to pursue multiple credentials from different institutions (Bayard \& Greenlee, 2009). For example, from 2000-2001 to 2006-2007, the number of college graduates pursuing degree programs at Ontario universities nearly doubled (Colleges Ontario, 2008).

However, attending both college and university to attain multiple credentials is a relatively recent phenomenon in Canada. To date, only British Columbia, Alberta, and Quebec have fully articulated transfer systems between colleges and universities. Consequently, relatively little research has been conducted on college-university transitions in Canada (Andres, 2001; Stewart \& Martinello, 2012), and much of the existing research explores the experiences of transfer students in the United States. Moreover, many of these studies focus exclusively on quantitative data such as transfer rates, GPA patterns, and withdrawal rates, without examining students' experiences in these programs (Gawley \& McGowan, 2006; Laanan, 2001). These quantitative studies generally involve students who have transferred to a university degree program before completing a college diploma program.

There has also been considerable research into the concept of "transfer shock" (Hill 1965, cited in Stewart \& Martinello 2012), a phenomenon where the GPAs of college-touniversity transfer students' overall performance, as measured by GPA, declines early in their university programs and then rebounds by graduation (Diaz 1992; Rhine, Milligan \& Nelson 2000, D’Amico, Dika, Elling, Alfozzine, \& Ginn, 2014).

\section{Motivation for College-University Transitions}

College students who transfer to university do so for many and varied reasons. A 2010 study commissioned by Colleges Ontario concluded that the primary reason students attend college prior to university is to "develop their academic skills and knowledge to better prepare them for university" (Centre for Spatial Economics, 2010, p. 7). In the 2007 Graduate Satisfaction Survey conducted by the Ontario Ministry of Training, Colleges and Universities, college students who transferred to a university degree program claimed 
that they were motivated to do so for various reasons, including career advancement; pursuit of a certificate, diploma, or degree; and higher earning potential (Decock, McCloy, Liu, \& Hu, 2011). Arnold (2011), identified high college grades as "the most influential element in encouraging and solidifying [college students' university] transfer plans" (p. 11). Students, themselves, identified company requirement and unemployment as insignificant motivators for transferring to a university program (Decock et al., 2011). Regardless of their motivation, some students purposely planned to earn a university degree by initially enrolling in a college program and then transferring into a related university program, without completing their college program (Bahr, Toth, Thirolf, \& Massé 2013). This route, more common in the United States and some Canadian provinces, results in the attainment of a university degree without a related college diploma or certificate, This is a much different outcome from that provided by a pathway program that, at minimum, results in the attainment of a college credential and a university degree. Furthermore, college entrance requirements are often lower than those of universities, and there are generally greater opportunities for part-time study in college programs than in university programs (Carter, Coyle, \& Leslie 2011), which may also attract students to the pathway program route to a university education. Finally, students may be motivated to pursue the pathway program option to improve their job prospects, save money, or both. In a pathway program, students may obtain a four-year university degree (and a college diploma) by spending at least two years in college and two years in university (the $2+2$ strategy) instead of four years in university, resulting in significant financial savings for students since Ontario university tuition is almost three times higher than college tuition. In fact, in a study conducted for the Higher Education Quality Council of Ontario, Trick (2013) ascertained that students and governments save money when students earn a university degree by combining two years at college with two years at university.

\section{Academic Readiness}

Several studies indicate significant differences between students' academic expectations at college versus those at university, and as a consequence transfer students may experience academic challenges when navigating college-university transitions (Hickey, 2008; Laanan, 2001; McGowan \& Gawley, 2006; Townsend, 1993). In a study of Ontario transfer students, Hickey (2008) noted that students felt underprepared for the coursework and assessment differences between colleges and universities. Hickey (2008) found that half of his study's participants $\left(\mathrm{n}_{\text {Total }}=22\right)$ felt underprepared for university degree programs in terms of reading speed, comprehension, critical thinking, writing skills, and exam-taking ability. In a related study, college students claimed that college faculty are inclined to be more involved and interested in their students' education than are university faculty (Bauer \& Bauer, 1994).

Other academic challenges faced by students include a lack of preparedness for the larger class sizes (Hickey, 2008; Townsend \& Wilson, 2006), inadequate academic preparation of study skills (Stewart \& Martinello, 2012), a general lack of academic involvement (Harrison, 1999; Laanan, 2001)), and difficulties with social integration (Wolf-Wendel, Ward, \& Kinzie, 2009), all of which caused students to feel isolated and anonymous (Hickey, 2008; Townsend \& Wilson, 2006). 
Although several studies indicate that college-to-university transfer students often feel unprepared for the academic challenges of university, other studies suggest that college students are as well, or better, prepared for the transition than direct-entry students because of their college experiences (Morrin, 2011; Stewart \& Martinello, 2012). Stewart and Martinello (2012) analyzed the administrative records (including mid-year and final grades) of 3,636 students who completed at least one of three selected first-year university courses. They discovered that college transfer students' final course grades were not significantly different from those of direct-entry students. In a 2010 study commissioned by Colleges Ontario, the Center for Spatial Economics interviewed a sample of nine university students on their experiences as transfer students. Excerpts from three students highlight the potential benefits of attending college prior to university:

I entered university after three years at college ... [I found that $\ldots$. . those of us from college were more interactive during class and participated more. We were more prepared, had good study habits, understood the importance of speaking with the professors, and of applied thinking.

College taught me how to be hands-on: how to write a press release, how to work computers, how to speak to people. University taught me how to think but not how to do. I very much benefited from going to college first and was able to get a lot more out of my university year than if I had gone there directly from high school.

The teachers at college were excellent and they prepared me well. The university courses picked up where the college course left off.

These students' comments indicate that university-bound students may benefit from prior experience in a college program. From their perspective, these benefits derived from the varied, albeit complementary, focus of each of the two institutions-colleges concentrating more on the development of practical skills and knowledge, universities focusing more on the development of conceptual and theoretical understanding.

\section{Social-Cultural Integration}

In addition to the academic challenges associated with class size, comprehension, writing skills, and assessment practices, transfer students often experience difficulties with social integration. Differences in age, maturity, and life experiences can lead to difficulty for transfer students to integrate socially with students in the receiving institution (Gawley \& McGowan, 2006; Hickey, 2008; Laanan, 2001). Transfer students may experience feelings of social isolation and loneliness, particularly if they transfer into upperyear programs where classmates have had time to form social alliances (Harrison, 1999; Hickey, 2008).

In spite of these challenges, research suggests that orientation programs may help alleviate some of the academic and social challenges students may experience when they transfer to university (Jacobs, Lauren, Miller, \& Nadler, 2004). However, other studies criticize orientation programs, indicating a need for better orientation practices to improve transfer student integration (Handel, 2011; Harrison, 1999; McGowan \& Gawley, 2006). Harrison (1999) highlights the need for universities to provide effective orientation 
activities for transfer students, by offering services directly related to the needs of transfer students, and by regularly monitoring transfer student progress. Handel (2012) criticizes existing orientation programs for transfer students, stating that such programs "are less prominent and, even if an institution offers one, it is almost always a slimmed down version of the freshman event" (p. 26). Cameron (2005) recommends that "a comprehensive transfer orientation program, located at the university, should be developed with a series of 2-hour workshops at the university prior to transfer" (p.40). In a study by Townsend and Wilson (2006), focusing on factors facilitating the transfer of college students into a large research university, students provided several recommendations for improving the university's orientation sessions, including (a) involving a previous transfer student to explain the transition process, (b) providing detailed information describing universityspecific study skills, and (c) detailing all services available to support transfer students.

Today, our understanding of the transition process for a student who has completed a college diploma and is transferring to a university degree program remains unclear. We can conclude from existing research from the United States that there will be challenges around academic and social integration (transfer shock) and, for some, around academic preparedness. The extent of these challenges is unclear because the pathway students are transitioning after having completed a college diploma and not from an incomplete college program. More challenging to assess are the effects of these elements on the persistence and graduation rates of pathway students. There is a clear need for additional research to better understand the challenges faced by pathway students transitioning from a college to a university learning environment. This study focused on pathway students transitioning into the BCom program, with attention given to the strengths and challenges exhibited in the transition and post-transition portions of their journey.

\section{The BCom Pathway Program Case Study}

This case study occurred at UOIT, a small public university in Ontario, Canada. The Faculty of Business and Information Technology, which grants a Bachelor of Commerce degree, is one of the largest on the campus, with a enrolment of just over 2,000 students. The Bachelor of Commerce Pathway program (BCom Pathway) was one of the first pathway programs at UOIT. It has evolved over time in response to changes in the standard fouryear BCom degree program and the experiences of the faculty in which the program was administered, with developments in the broader university pathway program (see Figure 1).

In 2005-2006, admission to BCom Pathway required prospective students to have a college diploma with a cumulative A average. Students then enrolled in the commerce "bridge program," which involved completing a series of five courses, including financial accounting, managerial accounting, Finance I, Finance II, and either statistics for nonbusiness diploma students or an elective. Upon successful completion of the five bridge courses with a minimum cumulative average of $\mathrm{B}$, students then entered a modified third year of the BCom program. The faculty also worked with Durham College to build an integrated pathway involving the college's two-year business diploma program (called PATHU, a short-hand for University Pathway), where students who performed well after their first semester entered a specialized program that integrated the five commerce bridge courses into their diploma requirements. These two related programs proved to be successful because students who performed well in the bridge program also performed 
well in the four-year BCom degree program. As a result, the faculty decided to reduce the admissions standard in 2008 to a cumulative B average in the candidate's college diploma. In 2010, the faculty completed a review of the BCom program, including the commerce bridge component. After the review, the faculty decided to alter the bridge courses to include business math, critical thinking and ethics, financial accounting, organizational behaviour, and finance. At the same time, the faculty also decided to change the minimum performance standard in the commerce bridge courses to a $\mathrm{C}$ minimum.

In 2010, the faculty also evaluated potential options specifically tailored to students completing business diplomas. The post-bridge maps for students transitioning from two-year college business programs provided them with the opportunity to continue in their majors and graduate with those majors as part of their overall BCom program. These students were also provided a second option to enter directly into a modified second term in the second year of the BCom program, with 45 credit hours of transfer credit. Students with an approved three-year advanced college business diploma were able to enter directly into the third year of the BCom program, with 60 credit hours of transfer credits, and were also allowed to continue in their diploma major without the completion of any bridge courses.

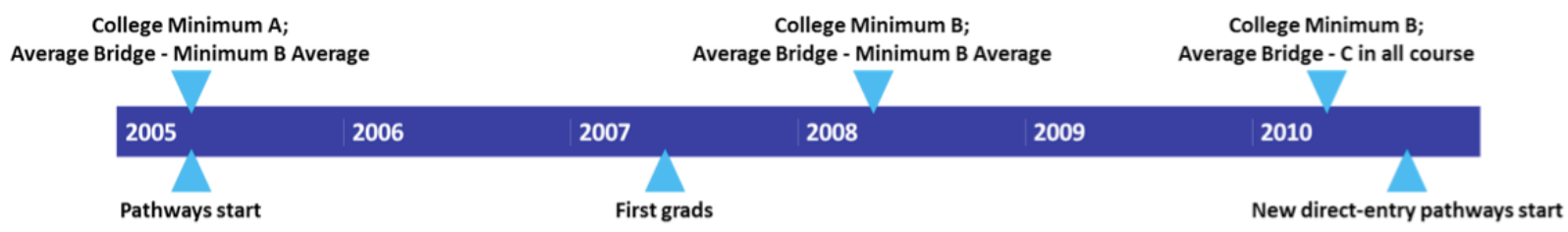

Figure 1. Timeline of pathway program implementation

\section{Methodology}

To achieve a broader perspective and richer portrayal of the pathway program under study, this research project employed a mixed-methods research design incorporating both quantitative and qualitative techniques (Johnson \& Onwuegbuzie, 2004; Teddlie \& Tashakkori, 2006). The entire analysis was positioned within the specific case study context of the commerce program at the host institution. In particular, a sequential mixedmethods plan was employed in which a quantitative phase preceded a qualitative phase. The quantitative analysis was based on a large data set $(17,881$ data points from courses alone) of student academic performance across a variety of courses in the case-study context over a seven-year period, with the qualitative data collection including a general university pathway student population survey and specific focus-group interviews with students currently enrolled in the specific-case context.

The quantitative phase involved collection and analysis of aggregate course grades data (2005-2011) and survey data to identify any significant challenges and/or successes experienced by BCom Pathway students, compared to those in the traditional four-year BCom Program. These objectives were met through use of application data, admissions data, student academic standing data, and individual course-level data. The academic performance dataset included data from 4,500 students across a representative sample 
of courses during the bridge transition as well as post-bridge core and elective business courses. In addition, student academic-standing data was used to identify potential pathway students who might participate in the study, and their academic performance per year. The application data was used to identify the entry point (particular pathway or directly from high school) for the student. This information was used later to identify the student type. Academic performance was then analyzed by student type for a set of core courses and by academic year of study to determine if the distribution of pathway student performance was significantly different from the performance of their traditiona, fouryear program counterparts.

The objectives of the qualitative portion of this study were to explore pathway student and academic advisor perceptions of, and experiences in, the BCom Pathway program. The first stage of qualitative data collection included a short online survey to obtain demographic data and initial views of strengths and weaknesses of the pathway program in general. The survey followed a holistic design (Rice, 2008), in which the entire transfer process is considered. It begins with a pre-transfer phase where students decide to enrol, and is followed by a transfer phase where students transition from college to university (including the completion of bridge courses, if applicable). This is followed by a posttransfer phase where students integrate into their university program and complete the pathway program requirements. The pre-transfer section included items on demographics, college program preparedness, and expectations regarding a four-year university program. To support analysis of the transition process, items regarding academic supports, course registration, transfer credits, and orientation were included. The final section focused on post-transition social and academic integration.

In November 2012, 272 current college-to-university pathway students were invited by email to participate in the online survey, and 39 students (14\%) completed the survey. A total of 127 graduates of the pathway program under study were invited to participate, and 9 students $(7 \%)$ completed the survey. Since survey participants did not identify their program of study at the university, these results are not included in detail in this paper but can be found in Percival et al (2016).

The survey also asked participants to provide their age, sex, and an indication of whether they were the first person in their family to attend a postsecondary institution. The most common pathway student age group was 21-24 years (44\%), with the rest of the participants distributed among the $17-20$ years (18\%), 25-29 years (15\%) and $35+$ years (15\%) age groups. In general, there is a relatively even distribution of participants from each gender and $59 \%$ of respondents to the survey were first-generation postsecondary students. This means that the pathway students tend to be older and more mature than their four-year traditional counterparts, and there is a higher percentage of pathway students who are first in their families to attend postsecondary institutions.

Participants who completed the survey were also asked to participate in follow-up focus group interviews. The intent of focus groups was to clarify survey responses and obtain fuller, more descriptive information regarding benefits and challenges associated with the pathway program. In general, focus group interviews concentrated on general transition and integration issues experienced by the pathway students, while the one-onone personal interviews focused on program-specific elements, such as transfer-credit allotments and bridge course requirements. Although eight students participated in the 
focus group and the subsequent one-on-one interviews, only two focus group participants were BCom Pathway students. In addition to pathway students, academic advisors were also invited to participate in focus group and one-on-one interviews. In particular, the two academic advisors who support the pathway students in the business department of the faculty were interviewed to determine their views of the pathway program and to provide an administrative perspective on the challenges students faced and the supports available to pathway students.

Qualitative data gathered in all focus group and personal one-on-one interviews were entered into NVivo10 data-analysis software for sorting, coding, and categorizing. Computerized analysis was also combined with manual analysis. In the analysis process, interview data were segmented, coded, and grouped into categories. Constant comparison of segments within and across categories enabled the researchers to clarify meanings and establish category significance in relation to the study's goals.

Although the quantitative analysis is based on 17,881 data points from over 4,500 students, it is important to acknowledge the study's qualitative design limitations: a small sample of BCom Pathway students $(n=2)$ and all BCom program academic advisors $(n=$ 2) involved in the focus group interviews does not represent the experiences of all BCom Pathway students. Selection of students for focus-group interviews was random in the sense that all students who participated in the broader research project were invited to participate in focus-group interviews and only two BCom Pathway students freely agreed to participate. The restricted timelines of the study, institutional transition to a new student email system, and the academic workload required for pathway students limited the ability of the students to participate in the focus groups. Thus, the study on which this paper is based should be treated judiciously as a limited case study because the results cannot be generalized to the entire student population.

\section{Factors Influencing Pathway Program Enrolment}

In the survey, students identified the primary factors motivating enrolment in the pathway program: future jobs, personal interest, parental or peer encouragement, unemployment concerns, and college professors. However, since the survey data is aggregate in nature, these influencing factors may not be representative of the entire population of BCom Pathway students. Analysis of focus group and personal interviews with the BCom Pathway student participants revealed three principle factors that influenced their decisions to enrol in the Pathway program: personal goals, program reputation, and financial constraints. For example, one student indicated that he "had a personal goal of getting a university degree," and remarked, "I'll be the first in my family to do so." The same student highlighted the program's positive reputation as another influencing factor:

I went to [the university] just because I heard the accounting professors were really good [compared to the] professors that we had in accounting at [the] college.

Another BCom Pathway student claimed that specific professional requirements also played a role, noting that, "[to work in] accounting, you need the classes to get the [required professional] designation and just doing it there made sense because [the university program] is accredited." By contrast, the previous [BCom.] Pathway student par- 
ticipant indicated that finance played a significant role in his decision to apply to the university, stating, "It made more sense for me to [attend a] university closer to home so that I could [live at home] and ... save money."

\section{BCom Pathway Program Transitions}

The analysis of the survey data from the broader pathway student population indicated that the university could do more to help pathway students transition from a college. Preliminary analysis of focus-group data involving BCom Pathway students indicated a similar trend, with these students highlighting both academic and social-cultural challenges that influenced their transition into university.

\section{Academic Factors}

A few pathway students said registration was a challenge, and some of the pathway program advisors interviewed identified problems in the areas of practice, particularly problems associated with registration and communication. The advisors explained that when pathway students register for courses, they are not given transfer credits for successful completion of college courses on a course-by-course basis, but are instead given a "block transfer credit," in recognition of the whole of their college studies. This ultimately affected pathway students' ability to register for particular courses because the registration system could not determine whether applicants had certain prerequisites. One advisor indicated that, "This is a real problem for students" because it obliges pathway students to enrol in courses they do not need or are not interested in.

In general, students taking bridge courses do not complete them until August. This means that they need to work with an academic advisor to conditionally enrol in their fall and winter semester courses, which can cause some confusion for pathway students who try to register online along with the traditional program students. One student commented on the need for earlier information on course selection for pathway students:

Near the end of your time at college ... you [need to] know that ... you're going on to university because you have to apply to it before the end of the college school year ...,[It would help if] you could get to know some of the [requirements] before you even finish that year, so you know what you're walking into the following September.

In addition to enrolment challenges, some BCom Pathway students felt they lacked some of the prerequisite knowledge and skills needed to meet with academic success in a university business program, including critical thinking and communication skills. One student described some of these perceived deficiencies, and suggested some solutions. He said one challenge was the increased expectations at university.

[In] college ... you just take something and you spit it back out, whereas [in] university [there is] a lot more critical thinking and theoretical work ... A summer semester [to improve finance or math course understand] or something like that [would help], but if they [offered] a writing workshop ... for case writing ... I think that would be more beneficial ... We know the accounting, we just don't know how to do the case work. 
Although they experienced some academic challenges in transitioning into the BCom Pathway program, the focus-group comments highlighted many positive aspects of the program, especially in terms of professors' instructional effectiveness and the useful assistance provided by professors and academic advisors. In answer to the question, "What do you like about your program and what are the strengths of your program?" one BCom Pathway student responded,

I would have to say, first off ... the teaching staff. A lot of them are accredited professionals, and they are really good at getting difficult ideas through to the students and explaining things ... they also make sure that we have time to ask them questions ... and they [are] available to discuss ... anything with us, and I think that is really important when you're pursuing a degree... [Our advisor] is really good. She helped us out quite a bit too.

\section{Social Factors}

Social factors also played a significant role in motivating some students to enrol in the BCom Pathway program. One student attributed his motivation to enter the program to "peer pressure and especially social influences, like parents." These influences also extended beyond family and friends to include college faculty. The two BCom Pathway students who participated in focus-group interviews indicated that faculty influenced their decision to transfer from college to university. One of these students admitted that she transferred to the university primarily because of the high regard one of her college professors had for his university counterpart.

Despite some feelings of readiness to begin university studies, some of the pathway students experienced social challenges in making the transition into university life. In focus-group interviews, the two BCom Pathway students indicated that social factors played a role in their transition into the BCom Pathway program. They highlighted three particularly challenging social factors: the absence of adequate orientation/information sessions, the difficulty of assimilating with non-pathway students, and the uncertainty about how to become actively involved in established student associations.

One area of concern for both B.Com Pathway students was the lack of adequate orientation to the campus and student life activities as they transitioned into the pathway program. Although the university provided some formal orientation activities for new students, some pathway students claimed they were not always aware of these orientation exercises and felt that orientation activities were directed at traditional, first-year students (direct entry from high school), not pathway students. In describing this challenge, one student stated, "[university administration] invited us to the 'new student' orientation, I think, the first year ... [but, we didn't attend] because it was geared more toward first-year [students] as opposed to transfer students in a higher year."

Assimilation for pathway students was particularly problematic during the first few weeks of class when these students were trying to find their place in the class culture at a time when the traditiona, four-year program students had been together for the previous two years. One BCom Pathway student reflected, "Walking into third year ... a lot of these kids [knew] each other," while the other BCom Pathway student expanded on this state- 
ment: "At the very beginning ... these kids see us walk in and you [feel] stigma[tized as if they are thinking], 'oh, these are college kids' that are just walking into our program."

The third factor causing frustration for the BCom Pathway students was their perceived inability to participate as active members of student associations (e.g., the Accounting Association) within the BCom program. They explained that, unlike many other student associations on campus, the Accounting Association provided opportunities for students to assume leadership roles that are viewed by many professional firms as key differentiators when hiring new graduates. The career benefits that these networking opportunities offer cannot be underestimated. According to a pathway student in the accounting program, traditional students join these associations in their first year, making it difficult for pathway students to become active members and assume leadership roles and derive corresponding benefits. The following exchange between the two BCom Pathway students exemplified this issue:

When you are transitioning from, say, a college program and [are] put directly in the third year, you don't really get the opportunity to join the [Accounting] association ... I was really interested in doing that and there [weren't] any opportunities for me to join throughout my university career because they are geared towards the students [in first or second year] ... So that was kind of a disadvantage for me, I felt, because ... I was actually really hoping to get involved in [the student account association].

Yeah, as opposed to just being a member [rather than] being able to be on the executive [or on a] committee, because the third- and fourth-year representatives are selected when they are in second year. We don't even know about [the organization] when they're being selected.

Although these statements do not indicate that the Accounting Association was unwelcoming to pathway students (or any other group of students), they do indicate that some pathway students did not feel welcome to join and actively participate in the association. As a consequence, these students assumed that obtaining a leadership role was not within their realm of possibilities.

\section{Academic Factors Influencing BCom Pathway Program Completion}

\section{Successes}

Given the preliminary nature of the data and its analysis, in this study we have focused on academic factors only. Aggregate GPA performance data were gathered for all traditiona, four-year BCom students, all pathway students in various BCom programs, and combined traditional/pathway students from 2005-2011, representing over 4,500 students, and 17,881 data points (Table 1). The GPA scores in this case study were calculated on a 4.3 scale, which is the scale used at the university under study. When a null hypothesis of the overall total GPAs of the pathway students was tested against that of the four-year cohort was found proportionately equal, it was rejected. The pathway students amassed $9.2 \%$ of the grade points even though they represented on $7.7 \%$ of the population $(p=$ 
o.ooo). Similarly, if considered by individual years only, the respective null hypotheses are all rejected. Using a resampling method to test the two cohort means we also found a 0.64 difference of magnitude, which is also significant. Finally, we computed a 2-sample t-test, which shows overwhelming significance for rejecting hypothesis where the averages are the same for both cohorts (all pairwise tests had $p$ values of 0.00o). As a result, the data in Table 1 clearly indicate that the pathway students who successfully matriculated into the BCom Pathway program performed significantly better, on average, than their traditiona, four-year program peers. Even in Year 2, where the grades relate to student performance in specific courses in the bridge, and there is a much higher standard deviation, students in the pathway program outperformed their traditional peer cohort.

Table 1.

Aggregate GPA Performance and Standard Deviations

\begin{tabular}{|c|c|c|c|c|c|c|}
\hline Program & Year 1 & Year 2 & Year 3 & Year 4 & Year 5 & Overall \\
\hline \multicolumn{7}{|c|}{ Traditional Four Year Students } \\
\hline Business & $\begin{array}{c}2.32 \\
(0.94)\end{array}$ & $\begin{array}{c}2.52 \\
(0.67)\end{array}$ & $\begin{array}{c}2.58 \\
(0.59)\end{array}$ & $\begin{array}{c}2.65 \\
(0.54)\end{array}$ & $\begin{array}{c}2.58 \\
(0.48)\end{array}$ & $\begin{array}{c}2.53 \\
(0.75)\end{array}$ \\
\hline \multicolumn{7}{|l|}{ Pathway Students } \\
\hline Business Bridge & & $\begin{array}{c}2.90 \\
(0.97)\end{array}$ & $\begin{array}{c}3.39 \\
(0.47)\end{array}$ & $\begin{array}{c}3.35 \\
(0.45)\end{array}$ & $\begin{array}{c}3.25 \\
(0.49)\end{array}$ & $\begin{array}{c}3.20 \\
(0.82)\end{array}$ \\
\hline Business PATHU & & & $\begin{array}{c}3.04 \\
(0.88)\end{array}$ & $\begin{array}{c}3.29 \\
(0.52)\end{array}$ & $\begin{array}{c}3.07 \\
(0.60)\end{array}$ & $\begin{array}{c}3.15 \\
(0.75)\end{array}$ \\
\hline \multicolumn{7}{|c|}{ Traditional \& Pathway by Major } \\
\hline Accounting & & & $\begin{array}{c}2.56 \\
(0.59)\end{array}$ & $\begin{array}{c}3.02 \\
(0.52)\end{array}$ & $\begin{array}{c}2.94 \\
(0.51)\end{array}$ & $\begin{array}{c}2.82 \\
(0.55)\end{array}$ \\
\hline Finance & & & $\begin{array}{c}2.37 \\
(0.46)\end{array}$ & $\begin{array}{c}2.64 \\
(0.49)\end{array}$ & $\begin{array}{c}2.44 \\
(0.40)\end{array}$ & $\begin{array}{c}2.47 \\
(0.40)\end{array}$ \\
\hline Marketing & & & $\begin{array}{c}2.35 \\
(0.52)\end{array}$ & $\begin{array}{c}2.55 \\
(0.52)\end{array}$ & $\begin{array}{c}2.51 \\
(0.49)\end{array}$ & $\begin{array}{c}2.48 \\
(0.52)\end{array}$ \\
\hline Human Resources & & & $\begin{array}{c}2.74 \\
(0.40)\end{array}$ & $\begin{array}{c}2.66 \\
(0.47)\end{array}$ & $\begin{array}{c}3.09 \\
(0.54)\end{array}$ & $\begin{array}{c}2.78 \\
(0.47)\end{array}$ \\
\hline
\end{tabular}

The data in Table 1 also indicate that students in the integrated pathway program from the college (Business PATHU line in the table) performed similarly to those in the bridge program. The Year 5 GPA scores for pathway students are relatively high, likely because these students stay at the university for an additional semester to complete the requirements for accreditation by professional accounting certification bodies. The higher performance of the BCom Pathway students may also be a result of their increased level of maturity, their increased focus on education, or their high levels of motivation to complete a university degree after successfully completing a college diploma.

In fact, academic preparedness, maturity, and self-motivation were highlighted as fac- 
tors contributing to success in the BCom Pathway program by some of the its academic advisors. For example, one of the two advisors interviewed provided a detailed description of a typical BCom Pathway student:

Academically, I would say, students who make it through the bridge ... [are] usually stronger students. They tend to be the students who win our awards. They're really motivated to work with the professors, and they do a lot of the extracurricular work with them. They go to competitions with their professors; they go to conferences. They are just much more engaged and I think that ... it may be [because they have] come out of the college system.

They were in a great program at the college that they were already engaged with, and I think that they kind of carry that through, and they've really made a conscious decision to be here, so ... they're just passionate about what they do.

Overall, [pathway students] tend to be a little more engaged [than traditional students]. It's not hard for me to find a bridge student to volunteer for something, because they check their e-mail, they watch for me to contact them, they come into my office on a regular basis. So they are very connected, I think, from my perspective.

In addition to compiling GPA scores by BCom program (Table 1), grade distributions of the core BCom courses were compiled (Figure 2), and the results of pathway students versus traditional students were compared. Over 13,000 data points representing every course attempt from 2005-2011 in the selected courses are represented in Figure 2 (955 pathway course attempts and 12,541 traditiona, four-year program course attempts). It is important to note that the counts are not independent, as individual students have taken a set of these courses. For this reason, it was not statistically valid to attempt comparative tests such as a chi-squared test.

The data in Figure 2 reveal some interesting patterns. In every key course for which pathway students versus traditional students were identified and the academic results compared, the distributions clearly showed a stronger grade performance (in aggregate) for the pathway group. This occurred whether the course was part of the bridge phase of the pathway program or whether it occurred after the student had already been fully integrated into the regular BCom program. This pattern is not just a shift in means, but in most cases is a systematic upward shift in students' grades across the entire grade spectrum.

If one considers a single course that has been consistently included as part of the commerce bridge, such as Finance I (Figure 3), a similar pattern as in Figure 2 is observed. The graph in Figure 3 includes the complete set of course attempts for Finance I (240 pathway course attempts and 1,944 traditional, four-year program course attempts). Conducting a chi-squared test to compare these two sets of students, a significant difference was determined $\left(\chi^{2}=95.840, d f=9, p=0.000\right)$, supporting the conclusion that these two populations are statistically different. Also, the chi-square test does not demonstrate that the mark distributions between the two groups are more than simply "different"; the shift is systematically towards the higher marks for the pathway students. 


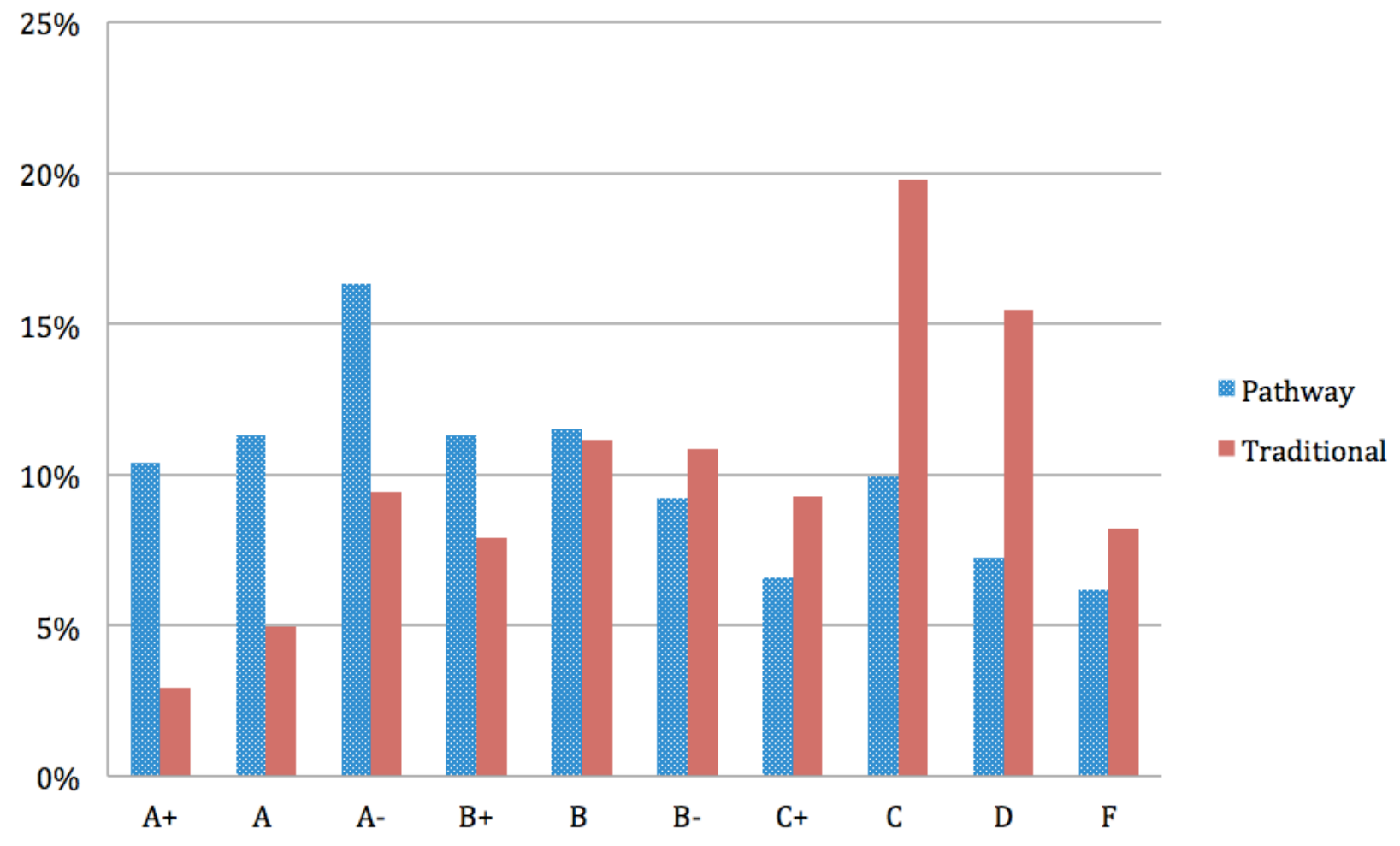

Figure 2. Grade Distributions for Core Business Courses.

(Includes Managerial Accounting, Marketing I, Organizational Behaviour, Finance I, Operations Management, Information Systems, Intermediate Financial Accounting I, Introduction to Taxation.)

It is important to also consider courses that occur only after a student has successfully

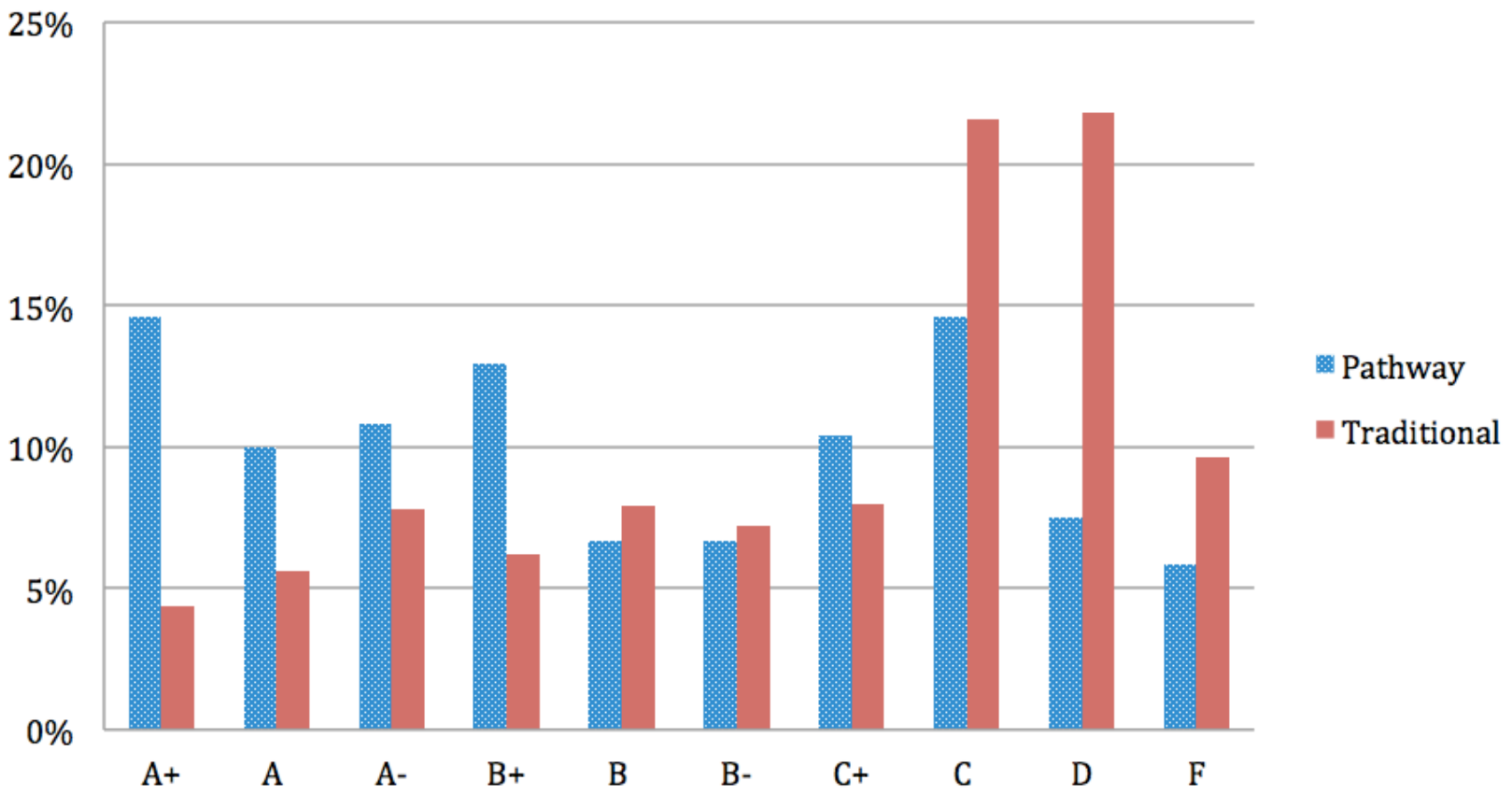

Figure 3. Grade Distributions for Finance I. 
completed the commerce bridge (Figure 4). One such example is the core, third-year Information Systems course. In this case, 135 pathway student course attempts and 1,609 traditional, four-year student course attempts were analyzed. Performing a chi-square test on this data, indicated that the two populations are significantly different, statistically $\left(\chi^{2}=84.895, d f=9, p=0.000\right)$.

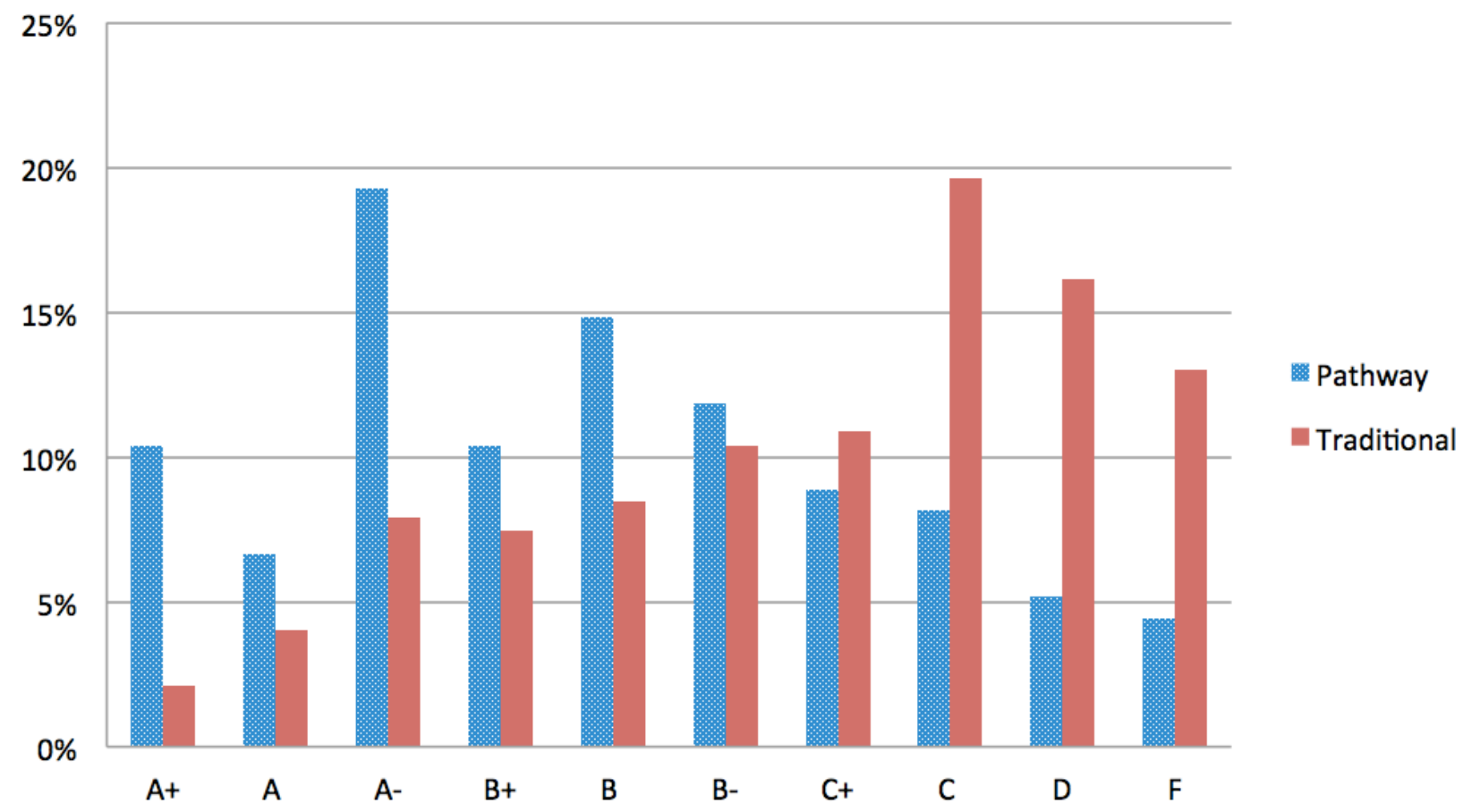

Figure 4. Grade Distributions for Information Systems

In this case, it is evident that the pathway student distribution is almost a mirror image of the traditiona, four-year program student distribution, with pathway students having remarkably lower proportions of grades in the lower quartile (for overall grades) and significantly higher proportions of grades in the top quartile. These figures demonstrate that there is a systematic difference between the distribution of pathway student performance and that of their traditiona, four-year program peer cohorts. This difference is more pronounced than that which can be inferred by considering cumulative GPA scores or course means alone.

\section{Challenges}

Although the BCom Pathway students met with academic success as demonstrated by their GPA results, the students also acknowledged challenges that impeded their academic success in the program. The BCom pathway students interviewed highlighted two specific challenges related to their lack of academic preparedness as they began their course work at the university: their deficiencies in writing skills and differences in academic expectations between the college and university. This was noted in a comment made in a earlier focus group; it highlights the challenges associated with writing case studies: 
We are going from not writing cases at all [in college], just doing [exercises such as] "here's a financial statement, write the financial statement." Whereas [in university the exercise] is "how is that . . . revenue? Explain why that's revenue?" That's a completely different type of question.

This student suggested that this challenge might be addressed by offering "a mandatory case-writing or communications class with the accounting professors, because that is who you are going to be working with over the next couple of years." The same student suggested that this would have been very beneficial because "if you can't write, you won't do well in any of the classes." Initial challenges caused by deficiency in writing skills were echoed by another student, who stated, "I would say the hardest thing that I had to deal with was . . . my writing skills. Coming from college to university [they weren't] necessarily at the same level." However, this student also emphasized that he experienced improvement in his writing skills as he progressed through the pathway program: "I would say now that I'm actually really good in writing . . . But, that was probably the biggest challenge in all my courses. Trying to explain what I had in my mind and put it on paper."

Another academic challenge identified in the interviews was the difference in academic expectations between the college and university. As an example, one student explained,

It's almost like the expectations from college to university ... college is [where] you just take something and you spit it back out. Whereas [at] university [there is] a lot more critical thinking and theoretical work ... they give you one thing for three years [at college], and then you try something else [at university].

Recognition of the differences in academic expectations were acknowledged by another student who described the discrepancy as follows:

College was more practical, so you didn't have to do as much theoretical [work], which is something that I kind of had an issue with at the start. But now I'm getting in the flow of it and there are no issues any more. It's something that you basically have to experience and get used to before you can actually do it properly.

\section{Conclusions}

The BCom Pathway program provides opportunities for college and university students to transition between institutions to complete degrees, certificates, and diplomas. Transitioning from a community college to a university can be an exciting and exasperating experience. The findings in this study indicate that while college students tend to succeed academically in their university programs, they experience challenges during the transition and integration phases of the transfer process. Pathway programs serve a useful purpose, providing opportunities for students to achieve their educational goals and prepare for desired careers. The existence of these programs should be publicized more broadly, given the value of possessing a college diploma and university degree in the global economy.

The BCom Pathway students in this study-like those surveyed in Arnold (2011)-were motivated to transfer from college to university in order to realize personal goals or enhance career aspirations. The general survey, showed that family members, friends, and college professors also influenced students' decisions to pursue a university degree after 
college. These positive influences and high college grades were factors that motivated the college students, who were interviewed in this case study, to enrol in the university BCom Pathway program. However, like their peers in other institutions, many BCom Pathway students approached their transfer to university with trepidation, often assuming they lacked prerequisite skills and knowledge, and concerned that they may not fit in socially (Stewart \& Martinello, 2012).

While the BCom Pathway students in this study were happy to be in the pathway program, some experienced academic, administrative, and social difficulties while transitioning into the program. Many of the academic challenges stemmed from transitioning to an increased focus on concept integration and case-based analysis of business problems. The expectation of thinking through problems critically was a difficult adjustment for many students to make.

Additionally, the majority of the administrative issues pathway students contended with were interconnected, the result of poor communication between BCom Pathway administrators, academic advisors, and BCom Pathway students. In some cases, students were placed in inappropriate courses, and in other cases, they were unable to enrol in required courses because online registration systems deemed them to lack prerequisites. Both BCom Pathway students and academic advisors blamed the block transfer-credit system for the majority of the enrolment problems, claiming that the system did not automatically keep track of pathway students' college course histories and required tedious and time-consuming manual input. These messy college-to-university transition situations meant some pathway students wasted valuable time and experienced much frustration.

The preliminary findings of this study indicate that the BCom Pathway students who participated in focus group interviews experienced some social-cultural integration issues. Some of the social concerns they anticipated before transferring to the university materialized after the transfer. For example, while none of the students interviewed experienced overt discrimination, students reported feeling isolated and excluded from some of the organized social activities within the university. In particular, establishing themselves in leadership roles in the Accounting Association or other BCom student clubs was nearly impossible due to the length of time it normally takes for these students to become active members in the clubs as well as the timing of elections for these roles. For students in this profession-oriented program, demonstration of leadership skills is a key criterion for internship and job offers at graduation. Feelings of social isolation may be alleviated by enhancing pathway program outreach to prospective student clubs and by engaging students in high quality pathway program-specific orientation that provides academic information and facilitates transfer students' integration into the social and cultural life of the university.

A preliminary analysis of the aggregate GPA data in this study indicates that, in general, BCom Pathway students outperformed their traditional, four-year university counterparts by a significant margin, even though students who were interviewed claimed they struggled early in their programs to meet university standards in thinking and writing skills. It should be noted that the academic requirements to qualify for the BCom Pathway program are so high (and historically were even higher) that many college diploma graduates are not be able to meet them. These entry conditions have proven to be strong indicators of student success in the BCom Pathway Program. 


\section{Recommendations and Future Research}

Preliminary findings in this study led to a number of suggestions for improving the college-to-university BCom Pathway Program. We recommend that the block transfercredit system be examined and modified (if necessary) to facilitate student registration and course enrolment in upper years. This method of assigning transfer credits seems to be a major factor in registration frustrations throughout the duration of the BCom Pathway student's study at the university.

Other areas of concern identified by BCom Pathway students and academic advisors in focus-group interviews include the lack of organized orientation activities for pathway students. We recommend the implementation of annual, organized orientation activities for BCom Pathway students that are tailored specifically to their needs. Orientation activities should provide detailed information about courses and programs, student clubs and associations, pathway student services, and career information. We also recommend the institution of optional summer workshops focused on the development of pertinent communication and critical thinking skills to support students in the bridge semester in their transition to the university environment.

The qualitative component of this preliminary case study had a small sample size. As such, future qualitative studies should aim to increase the number of study participants to increase validity and gain greater insights into the experiences of a broader segment of the pathway student and advisor populations. Moreover, a longitudinal study is necessary to better understand how the academic and social elements change over time while the students are enrolled in the BCom Pathway program. The longitudinal study should also include follow-up interviews with former students and their employers to determine the impact of the pathway program in improving former students' professional careers. Moreover, it would be of interest to ascertain if employers identify a significant difference (positive or negative) between pathway program graduates and their traditional, fouryear university counterparts.

Finally, there is a need to collect data from students who express interest in a BCom Pathway Program, but do not enrol in such a program. Although some initial challenges were identified by study participants, the students enrolled in the pathways programs are a small percentage of college graduates with the demonstrated academic ability to participate in a pathway program. Future research should aim to provide universities with the information they need to design effective pathway programs that increase access to degree-completion opportunities. For example, a research question might ask, What are the barriers that prevent students from attending a pathway program? This information would help improve pathway program design and inform public student financial aid policy development to increase access to pathway programs, thereby helping create a workforce prepared to compete in today's knowledge-based economy.

\section{References}

Andres, L. (2001) Transfer from community college to university: Perspectives and experiences of British Columbia students. The Canadian Journal of Higher Education, 31(1), 35-74. 
Arnold, C.H. (2011). Following the Ontario transfer student: From college to university inception. Canadian Society for the Study of Higher Education, Professional File 31, 1-19. Retrieved from http://csshescees.files.wordpress.com/2014/03/pf_31_arnold.pdf

Bahr, P. R., Toth, C., Thirolf, K., \& Massé, J. C. (2013). A review and critique of the literature on community college students' transition processes and outcomes in four-year institutions. In M.B. Paulsen (Ed.), Higher education: Handbook of theory and research (pp. 459-511). Dordrecht, Netherlands: Springer.

Bauer, P. F., \& Bauer, K. W. (1994). The community college as an academic bridge: Academic and personal concerns of community college students before and after transferring to a four-year institution. College and University, 69, 116-122.

Bayard, J. \& Greenlee, E. (2009). Graduating in Canada: Profile, labour market outcomes and student debt of the class of 2005. Ottawa: Statistics Canada Catalogue No. 81-595-M No. 074

Cameron, C. (2005). Experiences of transfer students in a collaborative baccalaureate nursing program. Community College Review, 33(2), 22-44.

Carter, I., Coyle, J., \& Leslie, D. (2011). Easing the transfer of students from college to university programs: How can learning outcomes help? Canadian Journal of Higher Education, 41(2), 10-27.

Centre for Spatial Economics. (2010). The financial benefits of enhanced college credential and credit recognition in Ontario. Retrieved from http://www.collegesontario. org/research/external-reports/financial_benefits_of_enhanced_college_credential_ credit_recognition.pdf

Colleges Ontario. (2008). Improving college system pathways: Project highlights report. Retrieved from http://www.collegesontario.org/research/studentmobility/CO_ ImprovingPathwaysHighlights_Septo8.pdf

D’Amico, M. M., Dika, S. L., Elling, T. W., Algozzine, B., \& Ginn, D. J. (2014). Early Integration and Other Outcomes for Community College Transfer Students. Research in Higher Education, 55(4), 370-399.

Decock, H., McCloy,U.,Liu,S\&Hu,B.(2011).Thetransferexperience ofOntariocolleges whofurther their education: An analysis of Ontario's college graduate satisfaction survey. Toronto, ON: Higher Education Quality Council of Ontario. Retrieved from http://www. heqco.ca/SiteCollectionDocuments/TransferExperienceofOntarioCollegeGraduates.pdf

Diaz, P. E. (1992). Effects of transfer on academic performance of community college students at the four-year institution. Community/Junior College Quarterly, 16(3), 279-291.

Gawley, T., \& McGowan, R. A. (2006). Learning the ropes: A case study of the academic and social experiences of college transfer students within a developing university-college articulation framework. College Quarterly, 9(3), 1-18. Retrieved from http://www. senecac.on.ca/quarterly/2006volognumo3summer/gawley_mcgowan.html

Handel, S.J. (2011). Improving student transfer from community colleges to four-year institutions: The perspective of leaders from baccalaureate-granting institutions. New York, NY: College Board. Retrieved from http://www.jkcf.org/assets/1/7/Perspective_ of_Leaders_of_Four-Year_institutions.pdf 
Handel, S. J. (2012). Increasing higher education access and success using new pathways to the baccalaureate: The emergence of a transfer-affirming culture. New York, NY: College Board. Retrieved from http://media.collegeboard.com/digitalServices/pdf/ rd/StephenJHandel-IncreasingHigherEducationAccess.pdf

Harrison, P. L. (1999). Transition experiences of community college transfer students: A qualitative study (Doctoral dissertation). Retrieved from: http://files.eric.ed.gov/ fulltext/ED461395.pdf

Hickey, T. (2008). The voyage of college to university transfer students: The student voice (Doctoral dissertation).

Jacobs, B. C., Lauren, B., Miller, M. T. \& Nadler, D. P. (2004). The college transfer student in America: The forgotten student. Washington, DC: American Association of Collegiate Registrars and Admissions Officers.

Johnson, R.B., \& Onwuegbuzie, A.J. (2004). Mixed-methods research: A research paradigm whose time has come. Educational Researcher, 33(7), 14-26. Retrieved from http://edr.sagepub.com/content/33/7/14.short

Laanan, F.S. (2001). Transfer student adjustment. New Directions for Community Colleges, 114, 5-13.

McGowan, R. A., \& Gawley, T. (2006). The university side of the college transfer experience: Insights from university staff. College Quarterly, 9(3). Retrieved from http:// www.collegequarterly.ca/2006-volo9-numo3-summer/megowan_gawley.html

Morrin, A. (2011). College to university transfer: An educational pipeline in support of social equity. College Quarterly, 14(4). Retrieved from http://collegequarterly.ca/2011vol14-numo4-fall/morrin.html

Ontario Ministry of Training, Colleges and Universities. (2009). Canada-Ontario Labour Market Agreement 2009-2010 Annual Plan. Retrieved from http://www.tcu.gov. on.ca/eng/training/labmark/LMA_Plan2009_10.html

Percival, J., DiGiuseppe, M., Goodman, B., LeSage, A., Longo, F., De La Rocha, A., Hinch, R., Samis, J., Sanchez, O., Rodrigues, A., Raby, P. (2016). Exploring Factors Facilitating and Hindering College-University Pathway Program Completion. International Journal of Educational Management, 30(1)..

Rhine, T.J., Milligan, D.M., and Nelson, L.R. (2000). Alleviating transfer shock: Creating an environment for more successful transfer students. Community College Journal of Research and Practice, 24, 443-453.

Rice, T. J. (2008). Riding out the waves: Community college transfers graduating with bachelor's degrees (Unpublished doctoral dissertation). Bowling Green State University, Bowling Green, OH..

Skolnik, M. (1995). Evolution of relations between community colleges and universities in Ontario. Community College Journal of Research and Practice, 19, 437-451.

Stewart, J., \& Martinello, F. (2012). Are transfer students different? An examination of first year grades and course withdrawals. Canadian Journal of Higher Education, 42(1), $25-42$. 
Teddlie, C., \& Tashakkori, A. (2006). General typology of research designs featuring mixed methods. Research in the Schools. 13(1), 12-28.

Townsend, B. K. (1993). University practices that hinder the academic success of community college transfer students. Memphis, TN: Memphis State University.

Townsend, B. K., \& Wilson, K. (2006). “A hand hold for a little bit”: Factors facilitating the success of community college transfer students to a large research university. Journal of College Student Development, 47(4), 439-456.

Trick, D. (2013). College-to-university transfer arrangements and undergraduate education: Ontarioinanationalandinternationalcontext.Toronto, ON: Higher Education Quality Council of Ontario. Retrieved from http://heqco.ca/SiteCollectionDocuments/ Transfer\%20Arrangements\%20Trick\%20ENG.pdf

Wolf-Wendel, L., Ward, K., \& Kinzie, J. (2009). A tangled web of terms: The overlap and unique contribution of involvement, engagement, and integration to understanding college student success. Journal of College Student Development, 5o(4), 407-428.

\section{Contact Information}

Jennifer Percival

Faculty of Business and Information Technology

University of Ontario Institute of Technology

jennifer.percival@uoit.ca

Ron Hinch, is a professor in the Faculty of Social Science and Humanities, University of Ontario Institute of Technology (UOIT). He was the founding dean of the faculty and initiated the first bridge program from Durham College (DC) to UOIT. His primary research areas include policing violent crime and the study of food crime (all the nasty things that get done to our food before we get to eat it).

Fabiola Longo is a full time nursing professor at Durham College teaching in the collaborative (DC/UOIT) BScN program and Year 1 coordinator. She is a Registered Nurse with 25 years nursing experience in all domains (clinical, administrative, educational, and research).In 2010-2011 she participated as a team member in a research project (Collaborative $\mathrm{BScN}$ program evaluation) with colleagues in the nursing program.

Jennifer Percival, is an associate professor and associate dean in the Faculty of Business and Information Technology, UOIT. Her research focus is in the area of management of technology, including process modelling, health informatics, and e-learning.

Bill Goodman is a professor in the Faculty of Business and Information Technology at UOIT, where he teaches statistics, forecasting and risk management. His research on tests to compare shifted distributions of outcome measures has been applied to medication-administration errors, student academic grade patterns, and, commercially, safety data at Ontario Power Generation, Health Canada, and elsewhere. His PhD is from the University of Waterloo, where he focused on knowledge-modelling, decision theory, and 
philosophy of education. He has published statistics textbooks and numerous papers on statistics and educational evaluation studies.

Arlene de la Rocha teaches in the collaborative Durham College/University of Ontario Institute of Technology Bachelor of Science nursing program in Oshawa, Ontario. Arlene's research interests include exploring the Registered Practical Nurses (RPN) students' performance and experiences as they bridge into a degree in nursing and as they transition into the role of Registered Nurses. Arlene is also involved in studying student engagement with technology such as high/low fidelity simulation and is researching the use of the iPad or iPhone at point of care, to support and enhance nursing students' confidence and competence with critical thinking, problem solving, and ethical nursing care.

Otto Sanchez graduated from medical school and held a residency in pathology in Colombia. His cancer research was advanced through his graduate work and a postdoctoral fellowship at the Princess Margaret Hospital. As a university educator, he developed expertise in online teaching while an instructor at a distance-education program in the Ontario. Inspired by McMaster's problem-based learning, he developed an interest in teaching basic health sciences with the use of case studies by adapting them to various educational formats. His teaching has been recognized by Teaching Excellence Awards by the McMaster's Students' Union and a University of Ontario Institute of Technology Faculty Teaching Award.

John A. Samis' research focuses on the role of host and pathogen proteases in coagulation health and disease. The research uses protein-based functional approaches to characterize the temporal and biochemical changes in coagulation factors and proteases that occur during the pathogenesis of experimental and clinical sepsis-induced disseminated intravascular coagulation. This research will not only lead to a greater understanding of the biochemistry of coagulation factors and proteases in healthy individuals and those afflicted with coagulation disorders, but the development of compounds and diagnostic assays to improve the quality of life and clinical care of Canadians afflicted with coagulation disorders. He has also applied his knowledge of science curriculum to evaluating the effectiveness of health science related pathway programs.

Ann LeSage is an assistant professor in the Faculty of Education, University of Ontario Institute of Technology. Her research focuses on elementary mathematics teaching and learning, including understanding the types of knowledge required to effectively teach elementary mathematics.

Maurice DiGiuseppe is an associate professor in the Faculty of Education at the University of Ontario Institute of Technology in Oshawa, Ontario. His areas of interest include teacher education, digital-learning resources, teacher education, environmental education, and access to postsecondary education. He has authored numerous elementary and secondary school science textbooks and digital-learning resources. 